\title{
Correlation between Picture Use in Test Format and Students' Vocabulary Achievement
}

\author{
Vedyanto \\ English Teacher Training and Education Faculty, Tanjungpura University \\ Prof. Dr. Haji Hadari Nawawi Street, Pontianak 78124, Indonesia \\ E-mail: vedy91@gmail.com
}

\author{
Doi:10.7575/aiac.alls.v.7n.1p.54 \\ URL: http://dx.doi.org/10.7575/aiac.alls.v.7n.1p.54
}

Received: 29/08/2015

Accepted: 01/11/2015

\begin{abstract}
This study investigated the correlation between picture use in test format and vocabulary achievement of 41 male and female seventh graders of Santu Petrus Junior High School. Hence, in this paper, the writer presents how strong the correlation between picture use in test format and vocabulary achievement of the seventh graders, and the students' attitudes towards picture use in test format. Measurement results or scores obtained from the tests given in this study were used in order to find the coefficient through Pearson product moment correlation. On the other hand, observations were applied to know the students' attitudes towards the assessment tool. The research resulted in a positive, very good correlation $(r=.84)$ between picture use in test format and vocabulary achievement of the students. Furthermore, the study found that stimulating students' vocabulary achievement through picture use in the test format is effective. Behaviourally, the students showed their focus, confidence, and enjoyment while doing the test with picture format as the test items were uncomplicated to understand.
\end{abstract}

Keywords: Correlation, Pictures, Test format, Vocabulary achievement

\section{Background}

Mastering English vocabulary is the sine qua non of learning English language. To give clarification, Zahedi \& Abdi (2012) claim, 'vocabulary plays an important role in English language skills. The greater vocabulary the students master, the better they perform their language' (p. 2264). Also, vocabulary is of great importance in communication because the communication will be unfeasible and discontinued if people hear or read words that they cannot understand (Abebe \& Davidson, 2012; Barani, Mazandarani, \& Rezaie, 2010; Richards \& Renandya, 2002; Scott, Jamieson-Noel, \& Asselin, 2003).

The increasing complexity in learning vocabulary is faced by a number of students particularly the ones studying in junior high schools. English is introduced to the students initially by learning vocabulary since it is a principal element that serves as a basis for other language skills such as listening, speaking, reading, and writing. Vocabulary becomes the core component of language proficiency (Richards \& Renandya, 2002, p. 255). Therefore, vocabulary fundamentally enables teaching and learning English. This idea is encouraged by Allen \& Valette (1994) that vocabulary is one of the important factors in all language teaching. Students must continually learn words as they learn structure and practice sound system (p. 149).

Regarding a success on learning vocabulary, apart from teaching approaches, test medium and format turn out to be factors that contribute essentially to the ability of the students to master vocabulary as they may have an effect on the students' achievement. To offer an unfavourable case in point, the students attempt to learn hard and understand the meanings of words in general; however, as the testing medium is poor and incapable to serve understanding, the students, as a straightforward result, encounter difficulties to do the tests.

Allen (1983) affirms that in classes where there is not any language that is known by the entire students, the teacher needs a particular teaching skill (p. 12). Agreeing with Allen (1983), Rokni \& Karimi (2013) elaborate, 'visual materials like pictures have an important role for improving vocabulary knowledge and learning process' (p. 237). Accordingly, teaching vocabulary by using pictures is worthy for both providing the learning inputs and testing instruments or media. Considering that using picture test format is an important instrument to support students' achievement, the teacher, consequently, should provide pictures in the teaching process and use relevant test media and format to assess the learning outcome.

In accordance with learning English as a Foreign Language (EFL) in Pontianak, Indonesia, students, especially the seventh graders of Santu Petrus Junior High School experientially encounter a number of vocabulary learning troubles. Based on the researcher's experience and observation, they are indicated by the little interest and motivation in studying English and inability to grasp the English teachers' explanations commonly due to the lack of vocabulary mastery.

A large number of researchers (e.g. Abebe \& Davidson, 2012; Ahmadi, 2014; Baleghizadeh \& Ashoori, 2011; Konomi, 2014; McLean, Hogg, \& Rush, 2013; Mohammadnejad, Nikdel, \& Oroujlou, 2012; Nemati, 2009; Rokni \& Karimi, 2013; Sitompul, 2013) bolster visual techniques as solutions to the obstacles of learning and conveying vocabulary; 
nonetheless, it is scarce to trace the ones dealing with pictures in test format correlating to vocabulary achievement. Therefore, filling in the research space is indispensable.

This research attempts to seek out the correlation between picture use in test format and vocabulary achievement of the seventh graders studying at Santu Petrus Junior High School in academic year 2014/2015. While the test is in progress, their attitudes are also in a careful observation. As the nature suggests, a correlational study is decided to be performed and its result is statistically interpreted based on the degree of correlation coefficient.

\section{Research Question}

The questions that the researcher focuses on to solve were: 'Is there any correlation between picture use in test format and vocabulary achievement of the seventh graders studying at Santu Petrus Junior High School in academic year 2014/2015?', 'What is the correlation?', and 'What are the students' attitudes towards picture use in vocabulary test format?'.

\section{Literature Review}

Concerning the details of some prominent areas that frame this study (e.g. vocabulary, picture, and the benefits of picture in learning vocabulary), the literature is reviewed in advance.

To unite words, people need a lot of collections of vocabularies. They express what people are going to say. Bachman \& Palmer (1996) elucidate vocabulary as 'the meaning and the usage of a set of words' (p. 12). Another definition proposed by Doff (1988) is that vocabulary is an important element systematically taught when it is linked with important grammar (e.g. attitudes, verbs, and adjectives) and a major topic area (e.g. names of facial feature character), and is specially practised in the units of a work book (p. 7). On the other hand, Scrivener (1994) explains, 'vocabulary is a powerful carrier of meaning. Beginners often manage to communicate in English by using the accumulative effect of individual words' (p. 43). Hackman (2008) further states, 'vocabulary is more than a list of words, and the size of one's vocabulary matters, especially in knowing how to use it' (p. 3). To exemplify the case, a student who says, 'Yesterday, go disco, and friends dancing.' tends to transform word by word from his source language to the target language without considering the grammar.

In a winning comparison to grammar, Wilkins (2002) reveals, 'vocabulary has to be equipped. Without grammar, very little thing can be conveyed; but without vocabulary, nothing can be applied, used, and conveyed' (p. 13). Hence, vocabulary ensures learners to deal with communication effectively since it includes the meaningful messages. Moreover, vocabulary proves to be in a wide usage amongst students in a learning community to activate the language.

In a classroom context, it is undeniable that getting familiar with vocabulary is absolutely indispensable for the students. However, the limitation on word memorisation occurs to hinder their vocabulary acquisition, and further to transfer information and give responses smoothly when having interactions with others. Moreover, Thornbury (2002) supportively points out that finding the right word to fit the intended meaning is frustrating when learners' store of words is limited (p. 2). To give solution to this case, the teacher should concern the materials with pictures. They are visual images representing objects, people, places or scenes produced on a flat surface, especially by painting, drawing, or photography. They also become a method and carry out the overall experiences (Gerlach \& Elly, 1971; Wright, 1989).

Hill (2001) clarifies that pictures meet a wide range of uses not only in acquiring vocabulary, but also in many other aspects of foreign language teaching and learning (p. 1). Considering their uses, pictures boost students' motivation to pay attention and participate at a classroom, contribute to the context of currently used language, provide information of a thing in a clear way, and properly stimulate students to speak, read, and write well.

Enormous existing advantages of pictures can be realised when the attention comes to Abebe \& Davidson (2012), Duke \& Moses (2003), and Silberman's (2007) elaboration that pictures yield the effectiveness of raising words consciousness, encourage the new words recognition, notice the special characteristics of words, attractively motivate, and create positive feelings like happiness and enjoyment towards learning in the educational context. Believably, the use of visual materials is a crucial way that makes the learners' memory immensely reliable of vocabulary learning (Gairns \& Redman, 1998; Rokni \& Karimi, 2013).

\section{Methodology}

This mixed quantitative and qualitative descriptive study was conducted to the seventh graders of Santu Petrus Junior High School, one of the private junior high schools in Pontianak, West Kalimantan, Indonesia. English is a foreign language used in this school.

The researcher's roles were as an observer and an examiner. Collecting and analysing the gathered data, making the interpretation, and drawing the conclusion on the findings were all activities in this research accomplishment.

There were 41 male and female seventh graders of classroom 7B actively participating in the observation. They were all randomly selected through a lottery procedure. This class consisted of the biggest number amongst the other 6 classes. Another English teacher was involved as a collaborator between the researcher and the students in this study.

To initially collect the data of this research, observations and techniques of measurement were employed. Observations were held in the aforementioned site in a one-teaching-hour session lasting for 20 minutes by using field notes.

For the measurement approach, however, two formats of test items (ten pictures and ten Indonesian vocabularies) were used as tools to collect the quantitative data in this research. These test items make efficient use of testing time (Read, 2000, p. 2). The materials of the test comprised things in the classroom, things in the bag, things in the house, animals, and public places in the city. Upon the conduct, each test took ten minutes. The two formats of the test were enhanced 
with and without pictures. The one with pictures required the students to complete the missing letters and then to match the pictures with the related target language, i.e. English words by drawing the lines, whereas the one without pictures were simply coped with through the translation of Indonesian vocabulary into English vocabulary by completing the missing letters.

In order to analyse the data found through the observations, the researcher used description and interpretation by grouping the collections of information. On the other hand, Pearson product moment correlation was applied for the data which were gathered through the measurement. It is a very useful statistic that indicates both the direction and the magnitude of the relationship between two variables without needing a scatterplot to show it (Ary, Jacobs, \& Sorensen, 2010, p. 129). SPSS version 22 was utilised to statistically compute the quantitative data and to find out the magnitude of the correlation result.

\section{Findings and Discussion}

\subsection{Quantitative Data Finding}

The quantitative data obtained from the test given were analysed with an obvious objective (i.e. to find out the correlation between picture use in test format and students' vocabulary achievement).

Table 1. Pearson Product Moment Correlation between Picture Use in Test Format and Students' Vocabulary Achievement

\begin{tabular}{llll}
\hline & & $\mathrm{X}$ & $\mathrm{Y}$ \\
\hline $\mathrm{X}$ & Pearson Correlation & 1 & $.840^{* *}$ \\
& Sig. (2-tailed) & & .000 \\
& $\mathrm{~N}$ & 41 & 41 \\
\hline $\mathrm{Y} \quad$ & Pearson Correlation & $.840^{* *}$ & 1 \\
& Sig. (2-tailed) & .000 & \\
$\mathrm{~N}$ & 41 & 41 \\
\hline **. Correlation is significant at the 0.01 level (2-tailed). \\
where: \\
X = picture use in test format \\
Y = students' vocabulary achievement
\end{tabular}

As shown in Table 1, concerning the correlation result, the coefficient is regarded to be very good $(r=.84)$ and gains the significance at the .01 level. When the correlations fall into the range from .66 to .85 , the coefficients would be considered very good (Creswell, 2012, p. 347). As a result, there is a very good correlation between picture use in test format and vocabulary achievement of the seventh graders studying at Santu Petrus Junior High School in academic year 2014/2015.

\subsection{Qualitative Data Finding}

The observations were divided into two circumstances, specifically when the students were given the test with and without clues (i.e. pictures). The researcher found out that the majority of the students could easily do the test format with pictures.

Emphasising and clarifying how the students behaved during the test conduct, they looked relaxed as they dealt with the test format with pictures; therefore, they relished doing it. On the contrary, when they filled in the missing letters by referring to the incomplete words without any pictures, they seemed very slow in answering the questions and looked anxious and perplexed. What the researcher observed during these two activities was obvious that they encountered a difficulty to think abstractly due to the absence of visual supports when doing the vocabulary test. While doing the one with visual supports, nevertheless, they seemed relaxed and found the test easy. The following two photographs show the students' activities while doing the test.

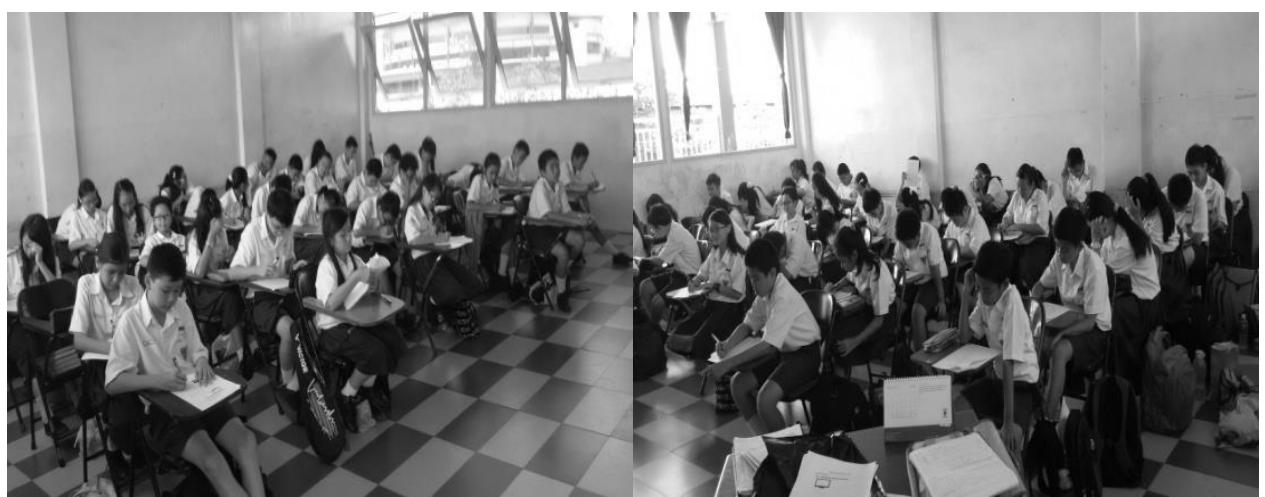

Figure 1. The Students' Activities while Doing the Test Formats with and without Pictures: Filling in the Missing Letters 
During the test, the collaborator of the researcher took field notes. The report of the testing process is divided into three sequences, such as before, during, and after the test. It is shown in Table 2:

Table 2. Field Notes

\begin{tabular}{|c|c|}
\hline Test Sequences & Notice of Observations \\
\hline \multirow[t]{19}{*}{ Before the test } & - $\quad$ The students gave greetings \\
\hline & and the researcher replied them back. \\
\hline & - $\quad$ Three students looked ready. \\
\hline & The researcher drew the \\
\hline & students' attention. \\
\hline & - $\quad$ Some students assumed that \\
\hline & there would be a difficult test for them. \\
\hline & - The researcher asked the \\
\hline & students to keep their books in their bags \\
\hline & and they did it. \\
\hline & - The researcher distributed the \\
\hline & pieces of test paper to all the students. \\
\hline & - The researcher explained the \\
\hline & test procedures and gave examples on the \\
\hline & blackboard. \\
\hline & • $\quad$ The researcher asked each \\
\hline & $\begin{array}{l}\text { student to write down his/her name, number, } \\
\text { and class. }\end{array}$ \\
\hline & - The researcher said 'start' and \\
\hline & the test started. \\
\hline \multirow[t]{16}{*}{ During the test } & $\begin{array}{ll} & \text { The condition was conducive. }\end{array}$ \\
\hline & - $\quad$ The students did the test with \\
\hline & their full concentration and confidence. \\
\hline & $\bullet \quad$ The researcher walked around \\
\hline & inside the classroom to see the students' \\
\hline & working process. \\
\hline & - $\quad$ The majority of the students \\
\hline & completed the missing letters before \\
\hline & drawing the lines. \\
\hline & - $\quad$ Three students finished the \\
\hline & $\begin{array}{l}\text { test in ten minutes and sat in a relaxed } \\
\text { manner. }\end{array}$ \\
\hline & - $\quad$ Two students thought deeply \\
\hline & when dealing with the second part of the \\
\hline & test. \\
\hline & - When the time was over, all \\
\hline & $\begin{array}{l}\text { the students stopped doing the test and } \\
\text { submitted it. }\end{array}$ \\
\hline \multirow[t]{8}{*}{ After the test } & Several students talked to \\
\hline & each other and checked the answers they \\
\hline & iously gave. \\
\hline & - The researcher asked the \\
\hline & $\begin{array}{l}\text { students to raise their hands to check the } \\
\text { part bringing the complexity to them. }\end{array}$ \\
\hline & - Twenty-five out of forty-one \\
\hline & students considered that the test with \\
\hline & $\begin{array}{l}\text { pictures was easier than the one without } \\
\text { them. }\end{array}$ \\
\hline
\end{tabular}

The researcher's interpretation was that the whole students were carefully managed and directed to have vocabulary test. Also, complete instructions and understandable examples were given before the test was conducted. During the test, particular attention came to the students as they intensely and tranquilly did the test. Most of them filled in the missing letters before drawing lines. In the end, after the test was over, sixty-one per cent of the students considered that the one with pictures was easy, while the other thirty-nine per cent represented those who difficultly did it.

Above all, the findings imply that it is recognised that the two variables are in the coefficient ranging from .66 to .85. In this positive way, correlation between picture use in test format and vocabulary achievement of the seventh graders studying at Santu Petrus Junior High School in academic year 2014/2015 exists. The result of the correlation coefficient 
that was calculated using Pearson product moment formula through SPSS version 22 shows that the correlation coefficient between picture use and vocabulary mastery is .84 and is significant at the .01 level.

Based on the analyses, the correlation between picture use in test format and vocabulary achievement is very good. This finding confirms Abebe \& Davidson (2012), Gairns \& Redman (1998), and Rokni \& Karimi's (2013) statements that the use of visual aids truly enables the language learning of vocabulary and boosts the students' motivation to have a fine achievement. In other comprehensible words, picture use in test format and vocabulary achievement are correlated each other.

Moreover on the evidence, through the observations during the testing process, it was discovered that the students showed their positive attitudes such as concentration, confidence, and enjoyment in doing the test format with pictures more greatly than with the one without pictures. Abebe \& Davidson (2012) supportively elucidate that the visual materials have the power to create a pleasant and enjoyable condition (p. 528). In the following sequence, i.e. after the test was over, most of the students admitted that the test format with pictures was easier than the one without pictures.

As a result, the quantitative data findings strongly agree with the qualitative ones. This shows the clarity that using pictures in test format is a good way to assess the students' vocabulary achievement. Coming along with these findings, some of the teaching experts (e.g. Gerlach \& Elly, 1971) also believe that using pictures in test format can well support, motivate, and stimulate the students to do the test.

\section{Conclusions and Suggestions}

This study with a mixed method particularly examined the correlation between picture use in test format and seventh graders' vocabulary achievement, as well as their attitudes. The test and field notes became supporting instruments used to collect both quantitative and qualitative data. Through the analyses and discussions, it could be summed up that there is a positive correlation resulting with a positive coefficient $(r=.84)$, being significant at the .01 level and reflecting a very good correlation. Consequently, it is obvious that positive attitudes appeared as pictures were dealt with.

Realising the benefits of visual supports on the students' vocabulary achievement, it is intensely recommended that the English teachers ought to employ the visual method, and continue applying and improving it for teaching-learning and testing activities.

\subsection{Study Weakness and Limitation}

This research may still lack its strength. A further study pertaining to its topic, thus, is inevitably needed for the advanced findings and benefits of vocabulary learning and assessment.

\section{Acknowledgement}

I specially appreciated Kristina Sutiah and Ardi Marwan whose valuable guidance cleared the matters while accomplishing this correlational study.

\section{References}

Abebe, T. T., \& Davidson, L. M. (2012). Assessing the Role of Visual Teaching Materials in Teaching English Vocabulary. Language in India, 12, 524-552.

Ahmadi, M. (2014). Semantic and Structural Elaboration in L2 Vocabulary Learning and Retention. Procedia - Social and Behavioral Sciences, 98(0), 109-115.

Allen, E. D., \& Valette, R. M. (1994). Classroom Techniques: Foreign Languages and English as a Second Language. Springfield: Waveland Press.

Allen, V. F. (1983). Techniques in Teaching Vocabulary. Oxford: Oxford University Press.

Ary, D., Jacobs, L. C., \& Sorensen, C. K. (2010). Introduction to Research in Education (Eighth ed.). Belmont: Wadsworth Cengage Learning.

Bachman, L., \& Palmer, A. (1996). Assessing Vocabulary. Cambridge: Cambridge University Press.

Baleghizadeh, S., \& Ashoori, A. (2011). The Impact of Two Instructional Techniques on EFL Learners' Vocabulary Knowledge: Flash Cards versus Word Lists. MEXTESOL Journal, 35(2), 1-9.

Barani, G., Mazandarani, O., \& Rezaie, S. H. S. (2010). The effect of application of picture into picture audio-visual aids on vocabulary learning of young Iranian ELF learners. Procedia - Social and Behavioral Sciences, 2(2), 53625369.

Creswell, J. W. (2012). Educational Research: Planning, Conducting and Evaluating Quantitative and Qualitative Research (Fourth ed.). Boston: Pearson Education, Inc.

Doff, A. (1988). Teach English: A Training Course for Teachers. Cambridge: Cambridge University Press.

Duke, N. K., \& Moses, A. M. (2003). 10 Research-Tested Ways to Build Children's Vocabulary. New York: Scholastic Inc.

Gairns, R., \& Redman, S. (1998). Working with Words: A Guide to Teaching and Learning Vocabulary. Cambridge: Cambridge University Press. 
Gerlach, V. S., \& Elly, D. P. (1971). Teaching and Media: A Systematic Approach (Second ed.). New Jersey: Prentice Hall.

Hackman, S. (2008). Teaching Effective Vocabulary. Nottingham: Department for Children, Schools and Families.

Hill, D. A. (2001). Visual Impact: Creative Language Learning through Pictures. Harlow: Longman Group UK Limited.

Konomi, D. K. (2014). Using Visual Materials in Teaching Vocabulary in English as a Foreign Language Classroom with Young Learners. Paper presented at the International Conference.

McLean, S., Hogg, N., \& Rush, T. W. (2013). Vocabulary Learning through an Online Computerized Flashcard Site. The JALT CALL Journal, 9(1), 79-98.

Mohammadnejad, S., Nikdel, H., \& Oroujlou, N. (2012). Reactivating EFL Learners' Word Knowledge by Means of Two Techniques: Flashcards versus Wordlists. International Journal of Linguistics, 4(4), 393-406.

Nemati, A. (2009). Memory Vocabulary Learning Strategies and Long-Term Retention. International Journal of Technical Education, 1(2), 14-24.

Read, J. (2000). Assessing Vocabulary. Cambridge: Cambridge University Press.

Richards, J. C., \& Renandya, W. A. (2002). Methodology in Language Teaching: An Anthology of Current Practice. Cambridge: Cambridge University Press.

Rokni, S. J. A., \& Karimi, N. (2013). Visual Instruction: An Advantage or A Disadvantage? What about Its Effect on EFL Learners' Vocabulary Learning? Asian Journal of Social Sciences and Humanities, 2(4), 236-243.

Scott, J. A., Jamieson-Noel, D., \& Asselin, M. (2003). Vocabulary Instruction throughout the Day in Twenty-Three Canadian Upper-Elementary Classrooms. The Elementary School Journal, 103(3), 269-286.

Scrivener, J. (1994). Learning Teaching. Oxford: Heinemann.

Silberman, M. L. (2007). The Handbook of Experiential Learning. San Francisco: Pfeiffer.

Sitompul, E. Y. (2013). Teaching Vocabulary Using Flashcards and Wordlist. Journal of English and Education, 1(1), $52-58$.

Thornbury, S. (2002). How to Teach Vocabulary. Harlow: Pearson Education Limited.

Wilkins, D. (2002). Linguistics in Language Teaching. Cambridge: Massachusetts Institute of Technology Press.

Wright, A. (1989). Pictures for Language Learning: Cambridge Handbook for Language Teachers. Cambridge: Cambridge University Press.

Zahedi, Y., \& Abdi, M. (2012). The Impact of Imagery Strategy on EFL Learners' Vocabulary Learning. Procedia Social and Behavioral Sciences, 69(0), 2264-2272. 